
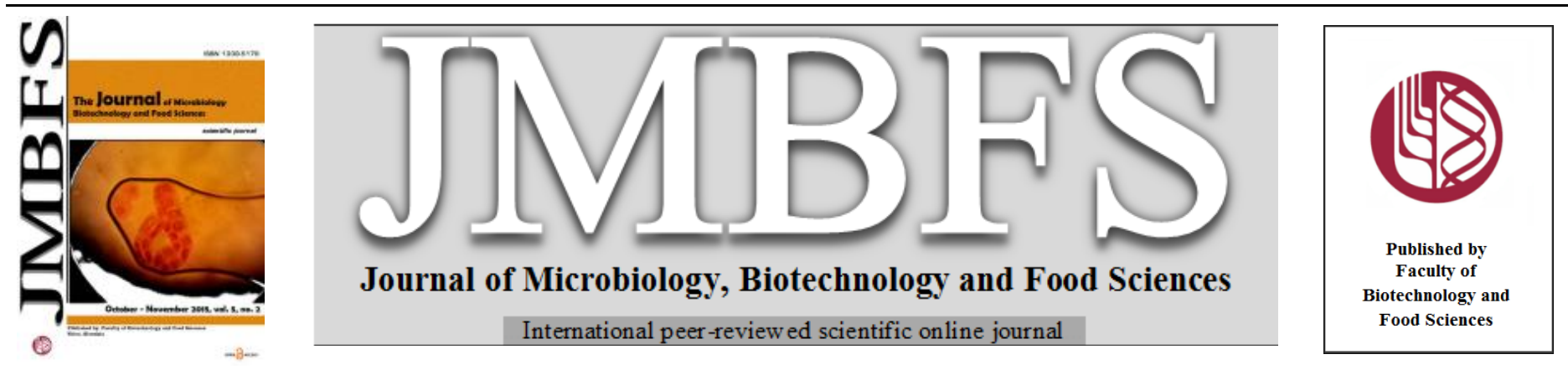

\title{
L-ASPARAGINASE AND L-GLUTAMINASE FROM Pseudomonas aeruginosa PAO1: PRODUCTION AND SOME PHYSICOCHEMICAL PROPERTIES
}

\author{
Sanghamitra Dutta ${ }^{1 *}$,Rajanya Roy ${ }^{2}$, Dibyajit Lahiri ${ }^{3}$ \\ Address(es): Dr. Sanghamitra Dutta, \\ ${ }^{1}$ Bengal Institute of Technology, Department of Biotechnology, Techtown, Dhapa Manpur, Kolkata- 700150,West Bengal, India. \\ ${ }^{2,3}$ Bengal Institute of Technology, Department of Biotechnology, Techtown, Dhapa Manpur, Kolkata- 700150,West Bengal, India.
}

*Corresponding author: dutta.sanghamitra@yahoo.co.in

doi: 10.15414/jmbfs.2015.5.2.142-146

\section{ARTICLE INFO}

Received 20. 6. 2014

Revised 19. 6. 2015

Accepted 30. 6. 2015

Published 1. 10. 2015

Regular article

oPEN $\odot$ ACCESS

\begin{abstract}
L- asparaginase (EC 3.5.1.1) is an enzyme which converts L- asparagine to L-aspartic acid and ammonia; L- glutaminase (EC 3.5.1.2) is an enzyme which catalyzes the conversion of L-glutamine to L- glutamic acid and ammonia. Both of these enzymes have been used in as chemotherapeutic agents. Among different sources of L- asparaginase and L-glutaminase enzymes producers, microbial strains possess an elevated edge over other enzyme producers; these enzymes produced by different microbial strains differ in some physiological, biochemical, catalytic and immunological properties. This led to the continuous screening program for isolation of novel microbial strains that could produce an effective enzyme with few limitations at use. A bacterial strain isolated from soil and identified as Pseudomonas aeruginosa PAO1 had been found to be capable of producing both extracellular L- Asparaginase and L- Glutaminase enzymes. The enzymes were produced under solid state fermentation. Effects of different fermentation parameters for production of these enzymes were determined. Some physicochemical properties of both of these enzymes were determined. The results obtained in this study revealed the potential of Pseudomonas aeruginosa PAO1 as a source of both L-Asparaginase and L- Glutaminase enzymes, which have gained significance in pharmaceutical industry. The uses of inexpensive agro- industrial wastes in this study have important economic advantages over submerged fermentation.
\end{abstract}

Keywords: Asparaginase; Glutaminase; Pseudomonas aeruginosa; Extracellular; Production; Thermostable

\section{INTRODUCTION}

L- asparaginase ( EC 3.5.1.1) is an enzyme which converts L- asparagine to Laspartic acid and ammonia has been used as a chemotherapeutic agent. It has received increased attention in recent years for its anti-carcinogenic potential (Manna et al., 1995).The clinical action of this enzyme is attributed to the reduction of L- asparagine, since tumor cells unable to synthesize this amino acid are killed by $\mathrm{L}$ - asparagine deprivation.

L- glutaminase ( EC 3.5.1.2) is an enzyme which catalyzes the conversion of Lglutamine to L- glutamic acid and ammonia. Tumour cells, more specifically lymphatic tumour cells unable to synthesize the L-glutamine unlike the normal cells hence require huge amounts of glutamine to keep up their rapid growth Hence the clinical action of L-glutaminase lies in the death of L-glutaminedependent tumour cells by depriving L-glutamine.

Among different sources of L- asparaginase and L-glutaminase producers, microbial strains possess an elevated edge over others due to their growth requirements, easy processing and handling etc (Satish et al., 2008). The literature reports suggested that these enzymes produced by different microorganisms differed in some physiological, biochemical, catalytic and immunological properties (Jeya Prakash et al., 2009; Mishra, 2006, ElBessoumy et al., 2004). This led to the continuous screening programme for isolation of novel microbial strains as effective producers of these enzymes with few limitations.In recent times, the bacterial systems are increasingly investigated for the production of enzymes and metabolites by solid-state fermentation (SSF) .The SSF has numerous advantages over submerged fermentation $(\mathrm{SmF})$, including superior productivity, simple technique, low capital investment, low energy requirement and less water output ,better product recovery and lack of foam build-up (Carrizales and Jaffe, 1986). Additionally, the utilization of agrowastes as a substrate for carbon and energy requirement under SSF makes this approach environment friendly. On the other hand extracellular enzymes are more advantageous than intracellular since they could be produced abundantly in the culture medium under normal conditions and could be purified economically. The objective of our study was to isolate bacteria from soil of sea coastal region capable of producing both L-asparaginase and L-glutaminase enzymes. In this paper we report the production of both extracellular L-asparaginase and Lglutaminase enzymes by an isolated strain of Pseudomonas aeruginosa PAO1 under SSF using Wheat Bran. Attempts were made to study the optimization of both L-asparaginase and L-glutaminase production and preliminary characterization of both of the crude enzymes.

\section{MATERIALS AND METHODS}

\section{Chemicals}

Various carbon sources like glucose, sucrose, lactose, soluble starch and nitrogen sources like sodium nitrate, yeast extract, ammonium sulphate, peptone and other chemicals like magnesium sulphate sodium chloride, disodium hydrogen phosphate, potassium dihydrogen phosphate, sodium hydroxide, sodium acetate, boric acid, sodium metaborate, hydrochloric acid, acetic acid and calcium chloride dihydrate were procured from E. Merck Pvt Limited (Kolkata, India) Other chemicals like L-Asparagine and L-Glutamine, EDTA, Tris buffer were obtained from SRL Pvt Limited (Mumbai, India).

\section{Microorganism and Media for maintenance and inoculation}

Pseudomonas aeruginosa PAO1 producing L-asparaginase and L-glutaminase was isolated from the soil of coastal region of Andaman( India). The bacteria was maintained in the modified $\mathrm{M}_{9}$ medium (Gulati et al., 1997) containing the following constituents $(\mathrm{g} / \mathrm{L}): \mathrm{NaH}_{2} \mathrm{PO}_{4} \cdot 2 \mathrm{H}_{2} \mathrm{O}-6 ; \mathrm{KH}_{2} \mathrm{PO}_{4}-3 ; \mathrm{NaCl}-0.5 ; \mathrm{L}-$ asparagine/L-glutamine- 5; 1 (M) $\mathrm{MgSO}_{4}, 7 \mathrm{H}_{2} \mathrm{O}-2 \mathrm{ml} ; 0.1 \mathrm{M} \mathrm{CaCl}_{2}, 2 \mathrm{H}_{2} \mathrm{O}-1 \mathrm{ml}$ $20 \%$ glucose stock solution - $10 \mathrm{ml}$; Agar -25 . pH7.0 0 0.2. The strain was subcultured at regular interval of time of 15 days at $37^{\circ} \mathrm{C}$. The composition of inoculum medium was the same except using agar to solidify the medium.

\section{Fermentation medium}

Different agro-wastes like rice husk, wheat bran, maize dust, bengal gram husk and husk of yellow lentil were used as a substrate. Ten grams of each substrate 
was measured into $250 \mathrm{ml}$ Erlenmeyer flask into which a supplemental salt solution was added properly to get the desired moisture level. The salt solution was composed of $\mathrm{Na}_{2} \mathrm{HPO}_{4} .2 \mathrm{H}_{2} \mathrm{O}-6 \mathrm{~g} / \mathrm{L}, \mathrm{KH}_{2} \mathrm{PO}_{4}-3 \mathrm{~g} / \mathrm{L}, \mathrm{MgSO}_{4} .7 \mathrm{H}_{2} \mathrm{O}-0.5 \mathrm{~g} / \mathrm{L}$ and $\mathrm{NaCl}-0.5 \mathrm{~g} / \mathrm{L}$. L-asparagine /L-glutamine were supplemented to induce synthesis of enzymes L-asparaginase and L-glutaminase, respectively (Gulati $\boldsymbol{e t}$ al., 1997).

\section{Screening of Asparaginase/Glutaminase Producing Organism}

L-asparaginase and L-glutaminase producing bacteria (antifungal agents Fluconazole $-75 \mu \mathrm{g} / \mathrm{ml}$ was added to control fungal contamination) were isolated separately from soil using plate and dilution technique (Salle, A. J., 1974). Each isolate was tested for its extracellular L-asparaginase and L-glutaminase activity (Hymavathi et al., 2009).The L- asparagine/ L- glutamine containing media were supplemented with $0.135 \mu 1$ of $2.5 \%$ of phenol red as an indicator. Two control plates were also prepared for both asparagine and glutamine - one was without dye while the other was without asparagine/ glutamine (using $\mathrm{NaNO}_{3}$ as a nitrogen source). L-asparaginase and L-glutaminase activity was identified separately by formation of a pink zone around colonies. Zone diameters were measured after $24 \mathrm{~h}$ of incubation at $37^{\circ} \mathrm{C}$. Based on the zone diameter colonies were picked up and broth studies were also carried out in order to compare the results obtained with the plate assay. Based on the zone diameter and broth studies a few colonies were selected and maintained on the asparagine / glutamine slants at $4^{\circ} \mathrm{C}$.

\section{Solid state fermentation and preparation of Crude Enzyme}

Inoculum was prepared by growing the organism in $50 \mathrm{ml}$ medium in $250-\mathrm{m}$ Erlenmeyer flasks incubated at $37^{\circ} \mathrm{C}$ for $24 \mathrm{~h}$ in a rotary shaker $(120 \mathrm{rpm})$. The sterilized fermentation media was inoculated with $2 \mathrm{ml}$ of inoculums, mixed thoroughly and incubated at $37^{\circ} \mathrm{C}$ for 4 days in a stationary condition. The recovery of crude L-asparaginase from the fermented material was done by simple extraction method. For this, the fermented substrate was mixed thoroughly with $50 \mathrm{ml}$ of $0.1 \mathrm{M}$ Tris- $\mathrm{HCl}$ buffer $(\mathrm{pH} 7.2)$ and the contents were agitated for 1 $\mathrm{h}$ at room temperature in a rotary shaker at $150 \mathrm{rpm}$. At the end of extraction, the liquid was filtered off through Whatman No. 1 filter paper and the final volume was made upto $50 \mathrm{ml}$, then the resulting clear filtrate was used for L-asparaginase / L-glutaminase assay.

\section{Assay Method}

Extracellular L- asparaginase / L- glutaminase activity was determined using Lasparagine / L-glutamine as a substrate and the product, ammonia, released during the catalysis was measured by using Nesseler's reagent (Imada $\boldsymbol{e t}$ al., 1973). One unit of enzyme activity was defined as the amount of enzyme that liberates $1 \mu \mathrm{mol}$ of ammonia under standard assay conditions.

\section{RESULTS AND DISCUSSION}

\section{Screening of L-asparaginase/L-glutaminase Producing Organism}

Fifteen strains having extracellular L-glutaminase and twelve strains having Lasparaginase activity were isolated from soil. Among these one isolate (ANG2) was selected for further studies as it showed the highest L-glutaminase activity (activity $191 \pm 1.02 \mathrm{IU} / \mathrm{ml}$ ). The organism ANG2 was allowed to grow in Lasparagine slant in an attempt to test whether it has any L-asparaginase activity or not and after that it's extracellular L- asparaginase activity was examined. The isolate ANG2 was also found to be a good producer of L-asparaginase enzyme and in fact the one with highest L-asparaginase activity (activity $170.33 \pm 1.05$ $\mathrm{IU} / \mathrm{ml}$ ) among the L-asparaginase producing strains. Hence the isolate ANG2 was taken for further studies as it showed the highest activities for both Lasparaginase and L-glutaminase enzymes.

\section{Taxonomical Studies}

The organism was identified on the basis of cultural and biochemical characteristics (Tab 1) following Bergey's Manual of Determinative Bacteriology (Holt et al, 1995). 16S rRNA sequence analysis was done by GCC Biotech, India and The Phylogenic tree is shown in figure 1. On the basis of 16S rRNA sequence analysis, figure 1, the isolate ANG2 has been identified as Pseudomonas aeruginosa PAO1 strain.

Table 1 Taxonomical characteristics of the selected strain ANG2

\begin{tabular}{|c|c|c|c|}
\hline & & PARAMETERS & CHARACTERISTICS \\
\hline \multirow[t]{2}{*}{ A) } & \multirow[t]{2}{*}{$\begin{array}{l}\text { CULTURAL } \\
\text { CHARACTERISTICS }\end{array}$} & Morphology & $\begin{array}{l}\text { Coccus occurring singly or in pairs, Non- } \\
\text { motile }\end{array}$ \\
\hline & & Staining Characteristics & Gram negative, Endospore formation \\
\hline \multirow[t]{2}{*}{ B) } & \multirow{2}{*}{$\begin{array}{l}\text { CULTURAL } \\
\text { CHARACTERISTICS }\end{array}$} & Nutrient Broth (Stationary Condition) $48 \mathrm{hrs}$ & $\begin{array}{l}\text { Moderate } \text { Growth, } \\
\text { Sedimentation, No ring and pellicle } \\
\text { formation }\end{array}$ \\
\hline & & Nutrient Broth (Shaking Condition) 48 hrs & $\begin{array}{l}\text { Turbidity, Abundant Growth, No ring } \\
\text { and pellicle formtion, Bluish green } \\
\text { colour of growth medium }\end{array}$ \\
\hline \multirow{6}{*}{ C) } & \multirow{6}{*}{$\begin{array}{l}\text { PHYSICO-CHEMICAL } \\
\text { CHARACTERISTICS }\end{array}$} & \multirow{3}{*}{ Growth at different Temperature } & \\
\hline & & & $30^{\circ} \mathrm{C}-$ Abundant \\
\hline & & & $10^{\circ} \mathrm{C}-$ Scanty \\
\hline & & \multirow{3}{*}{ Growth at different $\mathrm{pH}$} & $\frac{5.4-\text { Scanty }}{6.8-\text { Abundant }}$ \\
\hline & & & $6.8-$ Abundant \\
\hline & & & $9.6-$ Scanty \\
\hline \multirow{9}{*}{ D) } & \multirow{9}{*}{$\begin{array}{l}\text { BIOCHEMICAL } \\
\text { CHARACTERISTICS }\end{array}$} & $\mathrm{NH}_{3}$ from Arginine & + \\
\hline & & Catalase Test & + \\
\hline & & $\begin{array}{l}\text { Carbohydrate Fermentation } \\
\text { Carbohydrate Source }\end{array}$ & \multirow{6}{*}{$\begin{array}{ll}\text { Acid formation } & \text { Gas formation } \\
+ & - \\
+ & - \\
+ & - \\
+ & - \\
+ & -\end{array}$} \\
\hline & & 1) Sucrose & \\
\hline & & Dextrose & \\
\hline & & Mannitol & \\
\hline & & Lactose & \\
\hline & & 5) Starch & \\
\hline & & Indole Synthesis & - \\
\hline
\end{tabular}




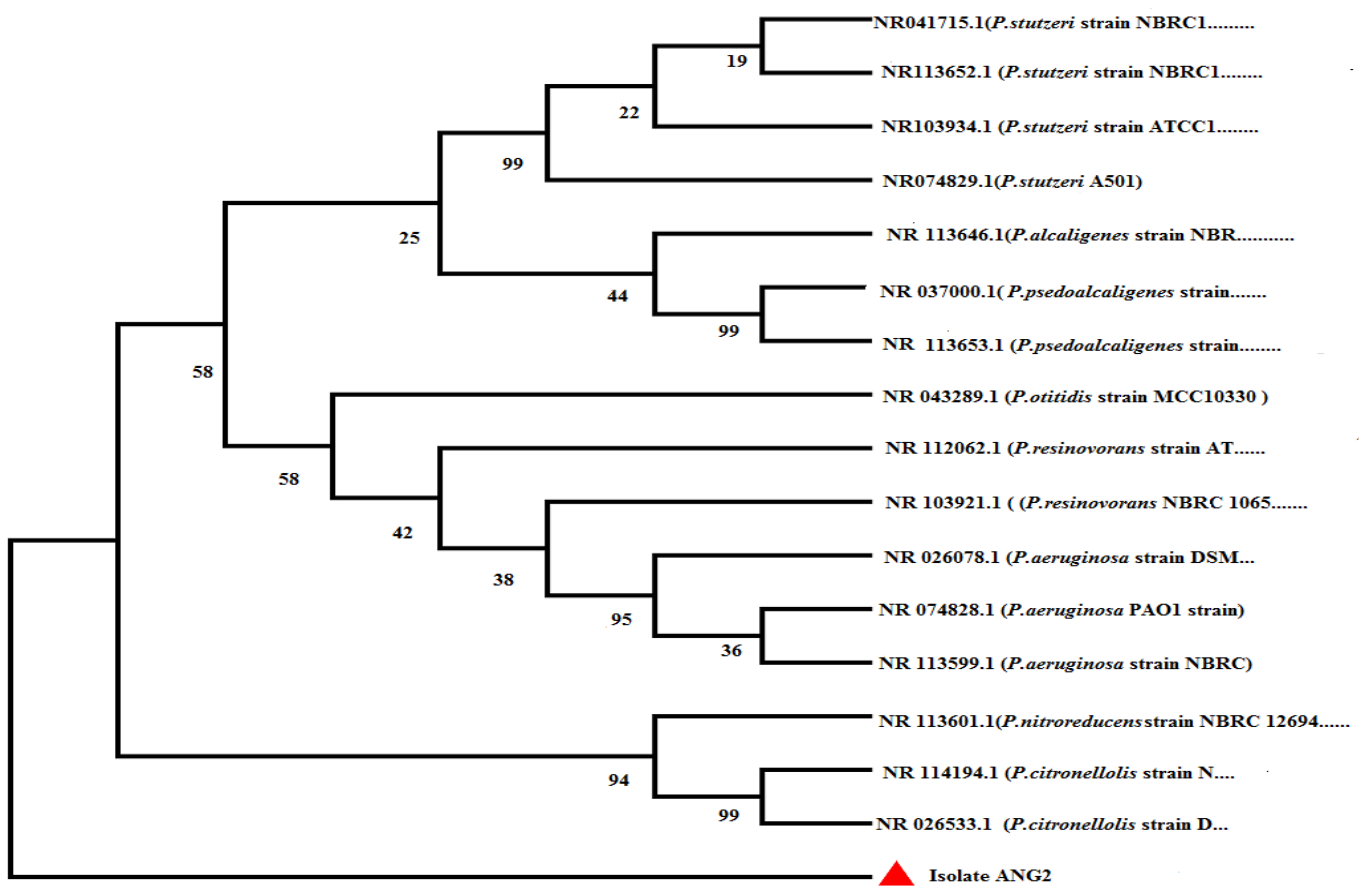

Figure 1 Phylogenic Tree

Fermentative Parameters for the Production of $\mathrm{L}$-asparaginase and $\mathrm{L}$ glutaminase

\section{Evaluation of different agro-residual substrates for L-asparaginase and $L$ - glutaminase production}

The screening of the best agro-waste as a substrate for maximum enzyme production in SSF process mainly depends on its easier degradation into nutrients and uptake by the bacteria to synthesize the targeted metabolite, its cost effectiveness and availability in nature. The present study revealed that production of extracellular L- asparaginase and L- glutaminase varied with the type agro-residual substrates. Maximal production of both enzymes by Pseudomonas aeruginosa PAO1was observed in the medium with wheat bran $(170.33 \pm 1.05 \mathrm{IU} / \mathrm{ml}$ for L-asparaginase and $191 \pm 1.02 \mathrm{IU} / \mathrm{ml}$ for L-glutaminase (figure 2). Wheat bran contains approximately $18 \%$ protein, $5 \%$ fat and $62 \%$ carbohydrate (Madruga, and Camara, 2000)) and is rather complete source of nutrients for microorganisms (Elliah et al., 2004; Beg et al., 2000).
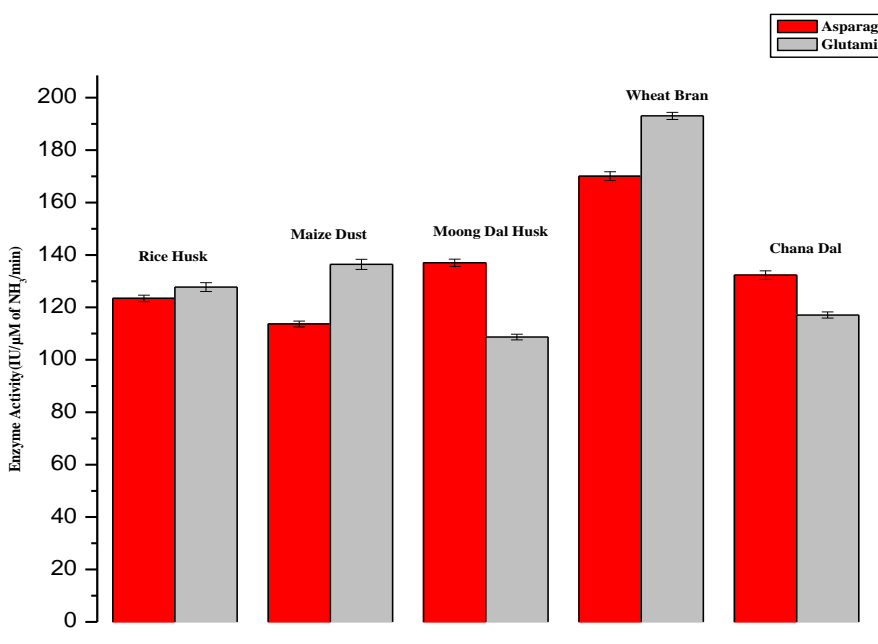

Solid Substrate

Figure 2 Evaluation of different agro-residual substrates for L-asparaginase/Lglutaminase production

\section{Effect of fermentation time}

Production of both extracellular L-asparaginase and L-glutaminase by Pseudomonas aeruginosa PAO1 were low initially and increased over time up to $96 \mathrm{~h}$ and then decreased. Upto 96h, the enzyme might be excreted in the fermentation medium due to lysis of the cell thus causing increase in extracellular enzyme production, figure 3 .

\section{Effect of moisture content}

Moisture content is one of the most significant factors under SSF using a specific substrate as it plays a key role in microbial growth and enzyme production. A maximum production of L-asparaginase $(242 \pm 0.42 \mathrm{IU} / \mathrm{ml})$ and L-glutaminase $(269.67 \pm 0.69 \mathrm{IU} / \mathrm{ml})$ was observed at $90 \%$ moisture level, figure 4 . A linear correlation between moisture content was observed until $90 \%$ and the enzyme activity declined sharply at further increase in moisture content

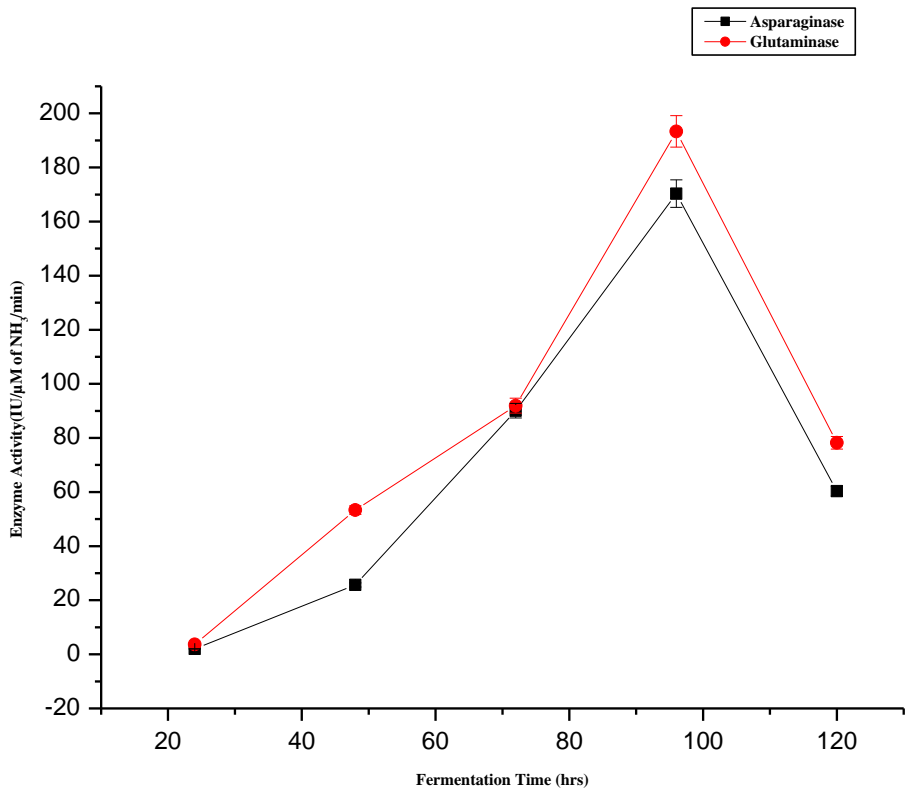

Figure 3 Effect of fermentation time on enzyme production 


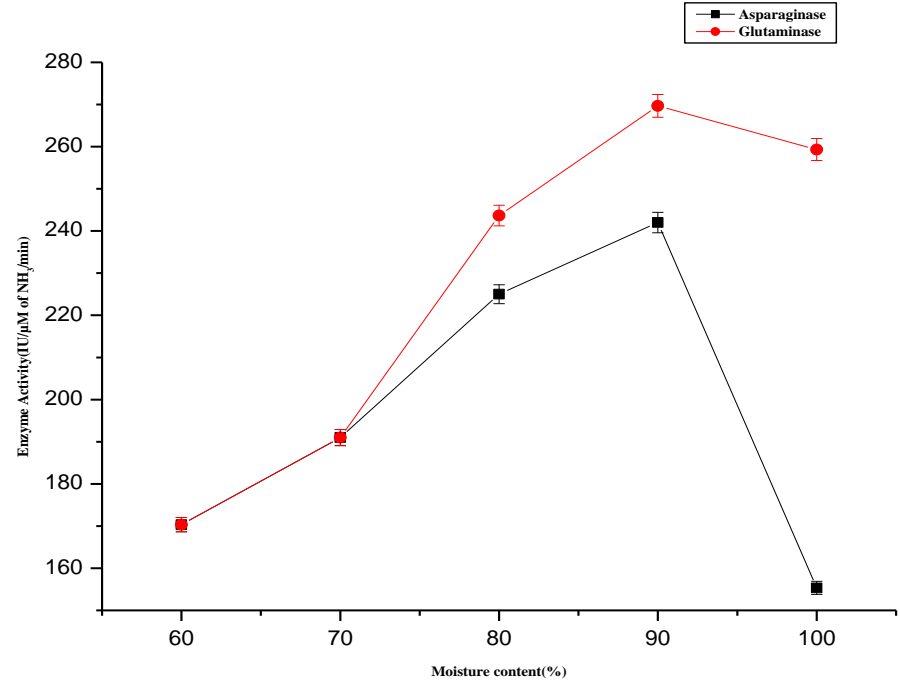

Figure 4 Effect of moisture content (\%) on enzyme production

\section{Effect of initial pH and temperature on enzyme production}

Influence of initial $\mathrm{pH}$ of the fermentation medium on the production of $\mathrm{L}$ asparaginase and L-glutaminase production by Pseudomonas aeruginosa PAO1 was studied over $\mathrm{pH}$ values 5.0-9.0. The experiment could not be conducted below $\mathrm{pH}$ value 5.0 or above 9.0 due to inhibition of growth of the microorganism. Maximum production of both the enzymes was revealed when the initial $\mathrm{pH}$ of the production medium was adjusted to 7.0. Fermentation was carried out at different temperatures (from $30-40^{\circ} \mathrm{C}$ ) and $\mathrm{pH}$ 7.0. There was a sharp rise in enzyme production with increase in temperature up to $37^{\circ} \mathrm{C}$ (Fig. 5).

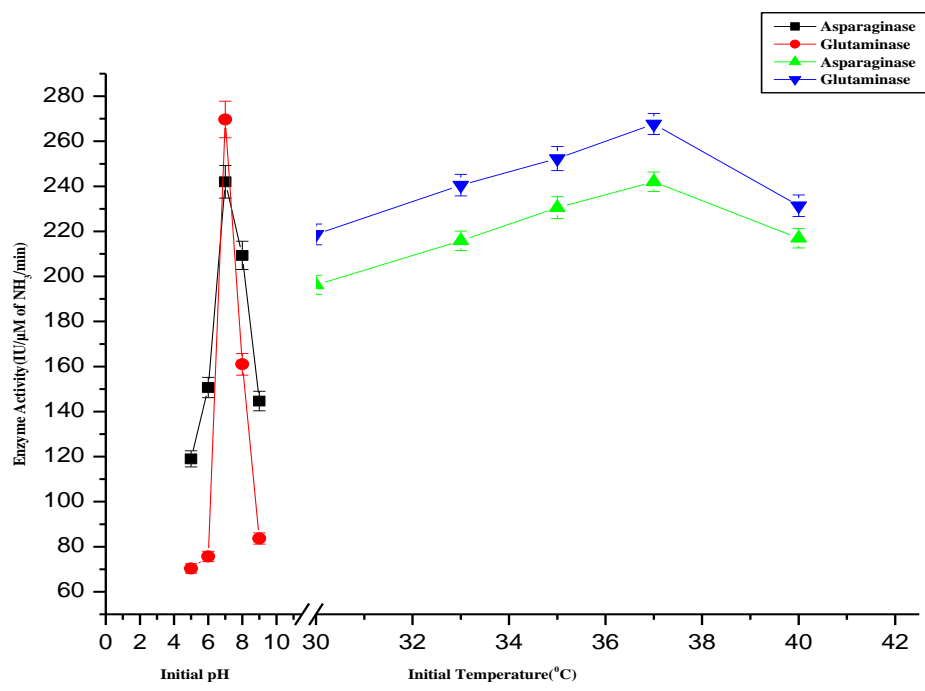

Figure 5 Effect of initial $\mathrm{pH}$ and temperature on enzyme production

\section{Effect of carbon and nitrogen sources on enzyme production}

In order to scrutinize the optimum carbon and nitrogen sources various carbon source like glucose, sucrose, lactose, soluble starch and nitrogen sources like ammonium sulphate, sodium nitrate, peptone and yeast extract were used as supplements separately $(1 \% \mathrm{w} / \mathrm{w})$ with wheat bran .But no such significant increase or decrease in enzyme activity observed for both the enzymes with such supplementations (Tab 2).
Table 2 Effect of carbon and nitrogen source on enzyme production

\begin{tabular}{lcc}
\hline \hline $\begin{array}{l}\text { Carbon Source } \\
(\mathbf{1 \%})\end{array}$ & $\begin{array}{c}\text { L-Asparaginase activity } \\
(\mathbf{I U} / \mathbf{m l})\end{array}$ & $\begin{array}{c}\text { L-Glutaminase activity } \\
(\mathbf{I U} / \mathbf{m l})\end{array}$ \\
\hline \hline Control & $242.48 \pm 4.84$ & $269.67 \pm 5.39$ \\
Glucose & $243.65 \pm 0.65$ & $267.34 \pm 1.76$ \\
Sucrose & $241.67 \pm 0.83$ & $269.34 \pm 2.34$ \\
Lactose & $239.56 \pm 2.43$ & $268.11 \pm 0.06$ \\
Starch & $240.43 \pm 1.56$ & $265.45 \pm 3.45$ \\
\hline \hline Nitrogen source & L-Asparaginase activity & L-Glutaminase activity \\
$(\mathbf{1 \% )}$ & $(\mathbf{I U} / \mathbf{m l})$ & $(\mathbf{I U} / \mathbf{m l})$ \\
\hline \hline Control & $242.48 \pm 4.84$ & $269.67 \pm 5.39$ \\
Ammonium & $244.56 \pm 0.56$ & $271.34 \pm 1.47$ \\
sulphate & $241.78 \pm 0.45$ & $267.54 \pm 2.34$ \\
Sodium nitrate & $240.24 \pm 3.42$ & $266.45 \pm 3.28$ \\
Yeast extract & $242.43 \pm 1.75$ & $269.34 \pm 1.59$ \\
Peptone & & \\
\hline
\end{tabular}

Physico-Chemical Properties of the Crude L-asparaginase and Lglutaminase

\section{Study of kinetic parameters}

L-asparaginase and L-glutaminase produced by Pseudomonas aeruginosa PAO1 exhibited hyperbolic response with increasing concentration of $\mathrm{L}$-asparagine and L- glutamine $(0.01,0.02,0.03,0.04,0.05,0.06 \mathrm{M})$, the assay substrates for the enzymes, respectively, figure 6 . The $\mathrm{K}_{\mathrm{m}}$ and $\mathrm{V}_{\max }$ calculated for L-asparaginase are $6.62 \times 10^{-2} \mathrm{M}$ and $242 \mathrm{mM} / \mathrm{min} / \mathrm{ml}$ and those for L-glutaminase are $7.3 \times 10^{-2} \mathrm{M}$ and $269 \mathrm{mM} / \mathrm{min} / \mathrm{ml}$ respectively. The low $\mathrm{K}_{\mathrm{m}}$ for both the enzymes suggests that they have high affinity for their respective substrates.

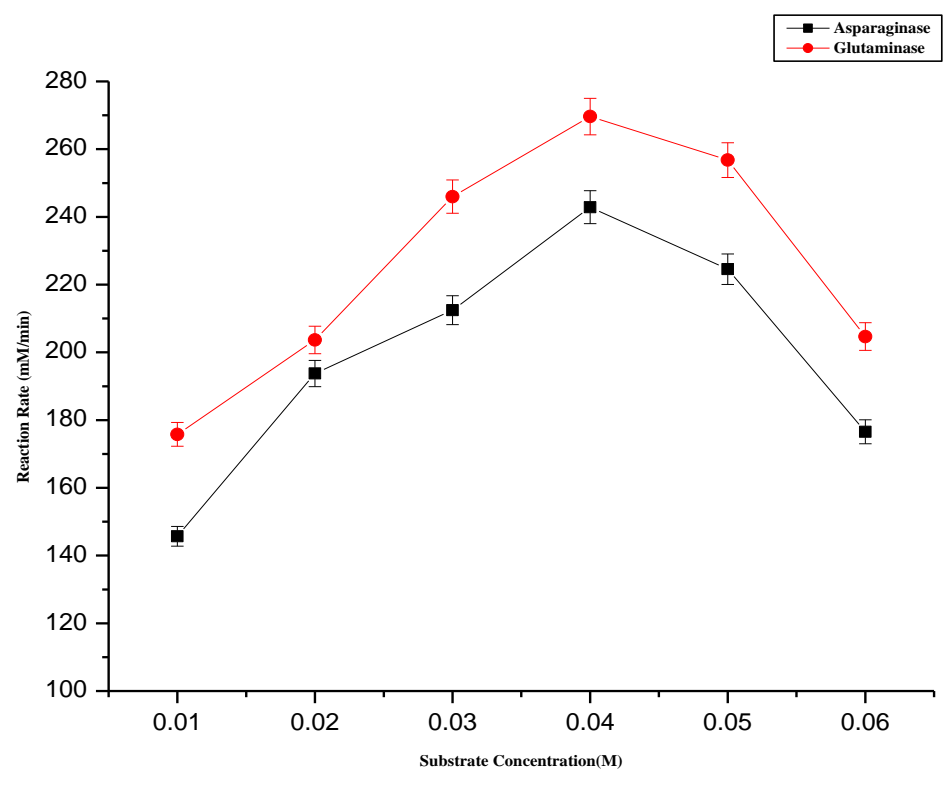

Figure 6 Effect of substrate concentration on enzyme activity

\section{Effect of pH on enzyme activity and stability}

Effect of $\mathrm{pH}$ on activities of L-asparaginase and L- glutaminase produced by Pseudomonas aeruginosa PAO1 were studied over a $\mathrm{pH}$ range 5-10 using Acetate buffer ( $\mathrm{pH} 5-6)$, Tris- $\mathrm{HCl}$ buffer ( $\mathrm{pH}$ 7.2-7.8), Borate buffer ( $\mathrm{pH} 8-10)$, figure 7. Maximum L-asparaginase activity was observed at $\mathrm{pH} 5.5$ (242.34 $\pm 2.34 \mathrm{IU} / \mathrm{ml}$ ), unlike majority of asparaginase reported earlier having alkaine $\mathrm{pH}$ optima (El-Bessoumy et al., 2004; Liboshi et al., 1999; Balcao et al., 2001); further increase in $\mathrm{pH}$ decreased the enzyme activity .L-glutaminase activity revealed $\mathrm{pH}$ maxima at $7.6(267.56 \pm 2.54 \mathrm{IU} / \mathrm{ml})$ like most microbial glutaminases having alkaline $\mathrm{pH}$ optima (pH 7.0-9.0) (Nandakumar et al, 2003;Wakayama et $\boldsymbol{a l}, \mathbf{2 0 0 5})$. $\mathrm{pH}$ stability of enzymes was detected after incubation in the $\mathrm{pH}$ range (5-10) for $1 \mathrm{hr}$ at the room temperature. The stability of enzymes showed similar trend like their activity with slightly diminished values, figure 7.

\section{Effect of temperature on enzyme activity}

Extracellular Pseudomonas aeruginosa PAO1 L-asparaginase and L-glutaminase activities increased progressively with increase of temperature from $30-60^{\circ} \mathrm{C}$, 
figure 8. The maximal activity for both L-asparaginase $(267.6 \pm 1.2 \mathrm{IU} / \mathrm{ml})$ and Lglutaminase $(306.54 \pm 3.57 \mathrm{IU} / \mathrm{ml})$ was observed at $50^{\circ} \mathrm{C}$. Glutaminase activity from Aspergillus sojae also showed its optimum temperature at $50^{\circ} \mathrm{C}$ (Ito et al.,2013). Thermostability of L-asparaginase produced by Pseudomonas aeruginosa PAO1 was examined by incubating the enzyme at different temperatures $\left(30-60^{\circ} \mathrm{C}\right)$ for $1 \mathrm{~h}$ at $\mathrm{pH} 5.5$, while thermostabilty of L-glutaminase was observed at the same temperature range for $1 \mathrm{~h}$ at $\mathrm{pH} 7.6$, figure 8 . It was revealed that even after incubating at $50^{\circ} \mathrm{C}$ for $1 \mathrm{~h}$, L- asperaginase and $\mathrm{L}$ glutaminase retained $98.12 \%$ and $87.87 \%$ of the activity, respectively, but the enzyme activity decreased sharply with further increase of temperature

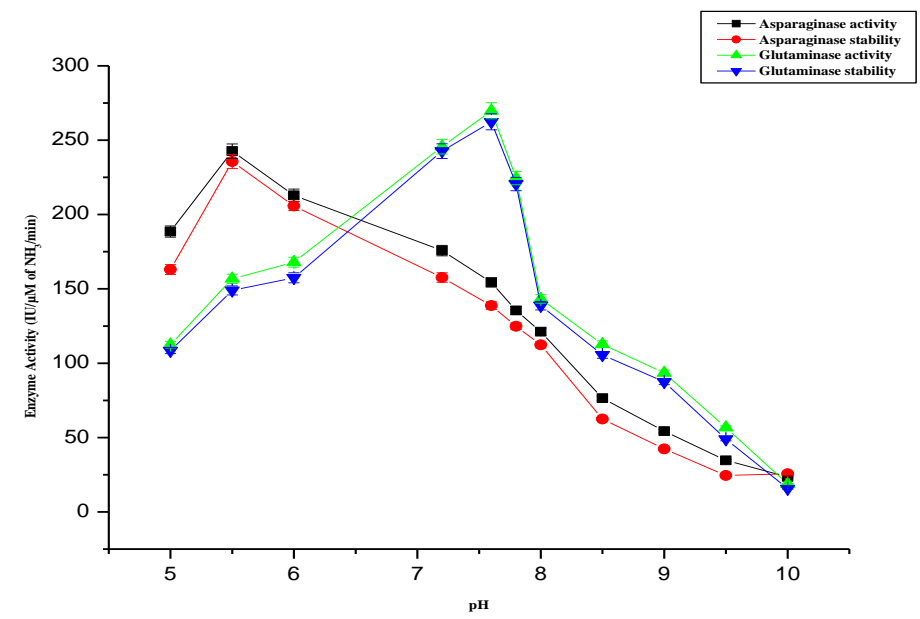

Figure 7 Optimum $\mathrm{pH}$ and $\mathrm{pH}$ stability of the crude asparaginase and glutaminase enzyme

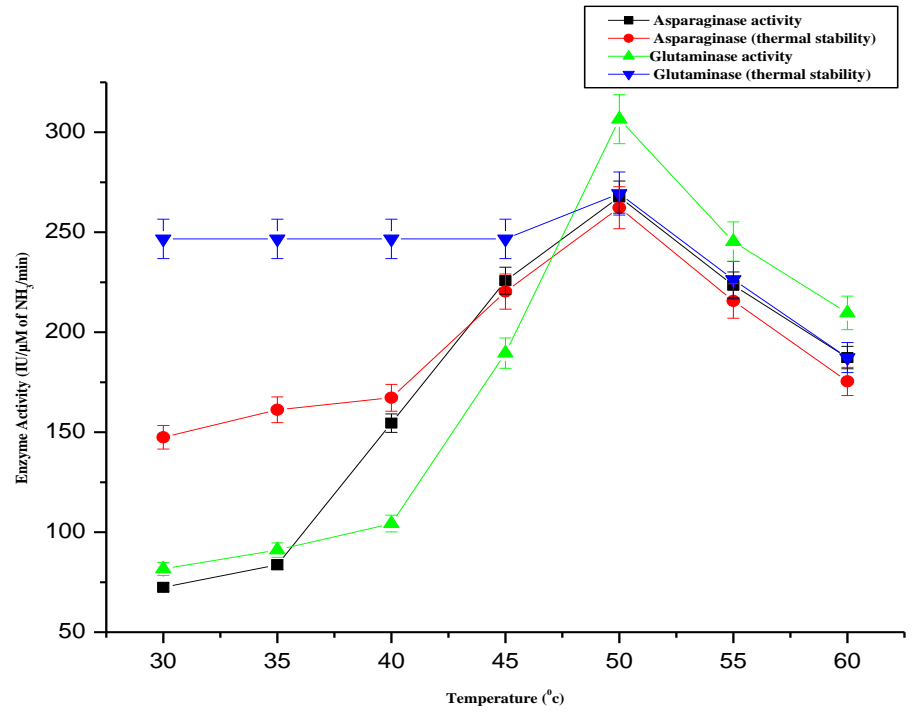

Figure 8 Optimum temperature and thermostability of the crude asparaginase and glutaminase enzyme

\section{CONCLUSION}

The study has been taken up with a view of exploring the possibilities of using Pseudomonas aeruginosa PAO1 as microbial source for the production of Lasparaginase and L- glutaminase enzymes, which have gained significance in pharmaceutical industry. The results obtained in this study revealed the potential of Pseudomonas aeruginosa as a source of both L-asparaginase and Lglutaminase enzymes, as both of these enzymes were found thermostable, with very low $\mathrm{K}_{\mathrm{m}}$ values. The use of inexpensive agro- industrial wastes for the production of enzymes has important economic advantages over submerged fermentation. Future work should involve purification of both of these enzymes to homogeneity and study of their antitumor activity on different human cell lines.
Acknowledgement: We thank Techno India Authority for extending financial support to carry out the project.

\section{REFERENCES}

BALCAO, V. M., MATEO, C., FERNANDEZ, L., LAFUENTE , R.; MALCOTA, F. X., Guisan, J.M.2001.Structural and functional stabilization of Lasparaginase via subunit: Immobilization on to highly activated supports Biotechnol. Prog, 17, 537-542. http://dx.doi.org/10.1021/bp000163r

BEG, Q.K., BHOSAN, B., KAPOOR, M., HOONDAL, G. S. 2000. Enhanced production of thermostable xylanase from Streptomyces sp. Qg11-3and its application in biobleaching of eucalyptus Kraft pulp. Enzyme and Microbial Technology, 27,459-466. http://dx.doi.org/10.1016/S0141-0229(00)00231-3

CARRIZALES, V., JAFFE, W. 1986. Solid -state fermentation: an appropriate biotechnology for developing countries, Interscience , 11, 9-15.

ELLAIAH, P., SRINIVASULU, B., ADINARAYANA, K. 2004. Optimization studies on neomycin production by a mutant strain of Streptomyces marinensis in solid state fermentation, Process Biochemistry, 39, 529-534. http://dx.doi.org/10.1016/S0032-9592(02)00059-6

EL-BESSOUMY, A. A., SARHAN, M, MANSOUR, J. 2004. Production, Isolation and Purification of L-Asparaginase from Pseudomonas aeruginosa 50071 using solid state fermentation , Journal of Biochemistry and Molecular Biology, 37(4), 387-393. http://dx.doi.org/10.5483/BMBRep.2004.37.4.387

GULATI, R., SAXENA, R.K., GUPTA, R.1997.A rapid plate assay for screening L- asparaginase producing microorganisms, Lett. Appl. Microbiol., 24, 23-26. http://dx.doi.org/10.1046/j.1472-765X.1997.00331.x

HOLT, J. G., KRIEG; N. R., PETER, H. A. S., BERGY, D. H. 1994. Bergy's manual of determinative Bacteriology. 9th edit. Lippincott Williams \& Wilkins, Philadelphia.

HYMAVATHI, M., SATISH, T., RAO, S.C., PRAKASHAM, R. S.2009. Enhancement of L - asparaginase production by isolated Bacillus circulans (MTCC 8574) using response surface methodology, Appl. Biochem. Biotechnol, 159 (1), 191- 198. http://dx.doi.org/10.1007/s12010-008-8438-2

IMADA, A., IGARASI, S., NAKAHAMA, K., ISONO, M.1973.Asparaginase and glutaminase activities of microorganisms, Journal of General Microbiology, 6(1), 85-99.

ITO, K., HANYA, Y., KOYAMA, Y. 2013. Purification and characterization of a glutaminase enzyme accounting for the majority of glutaminase activity in Aspergillus sojae under solid-state culture, Appl. Microbiol. Biotechnol. , 19 8581-90. http://dx.doi.org/10.1007/s00253-013-4693-4

PRAKASH,J.,POORANI,E.,ANANTHARAMAN,P.,

BALASUBRAMANIAM,T.2009.L-Glutaminase production and the growth of marine bacteria, Research Journal of Micrbiology,4(4),168-172. http://dx.doi.org/10. 3923/jm.2009.168.172

LIBOSHI, Y., PAPST, P. J., HUNGER, S. P., TTERADA, N.1999. Lasparaginase inhibits the rapamycine-targeted signalling pathway, Biochem.Biophys.Res.Commun, 260, 534-539. http://dx.doi.org/10.1006/bbrc.1999.0920

MADRUGA, S., CAMARA, S. 2000. The chemical composition of Multimistura as a food supplement, Food Biochemistry, 68, 41-44. http://dx.doi.org/10.1016/S0308-8146(99)00152-1

MANNA, S., SINHA, A., SADDUKAN, R., CHALRABORTY, S.L. 1995. Purification, characterization and antitumor activity of L-asparaginase isolated from Pseudomonas stutzeri MB-405, Curr.Microbiol., 30, 291-298. http://dx.doi.org/10.1007/BF00295504

MISHRA, A. 2006. Production of L-asparaginase and anticancer agent, from Aspergillus niger using agricultural waste in solid state fermentation, Appl. Biochem. Biotechnol,135(1),33-42. http://dx.doi.org/10.1385/ABAB:135:1:33 NANDAKUMAR,R.,YOSHIMUNE,K.,WAKAYAMA,M.,MORIGUCHI,M.200 3,Molecular glutaminase: biochemistry, molecular approaches and applications in food industry, Journal of Mol. Catal. B: Enzymatic , 23,87-100. http://dx.doi.org/10.1016/S1381-1177(03)00075-4

SALLE, A. J. (1974). Text book of bacteriology (7th ed., p. 274). New Delhi: McGraw Hill Publishing Co. Ltd.

SATHISH, T., LAKSHMI, G.S., RAO, C.S., BRAHMAIAH, P PRAKASHAM, R.S. 2008.Mixed design as first step for improved glutaminase production in solid-state fermentation by isolated Bacillus sp RSP-GLU, Letters applied Microbiology,47, 256-262. $\quad$ http://dx.doi.org/10.1111/j.1472 765X.2008.02413.X

WAKAYAMA,M.,YAMAGATA,T.KAMEMURA,A.,BOOTIM,L.,YANO,S.20 05.Characteriztion of salt-tolerant glutaminase from Stentrophomonas maltophilia NYW-81 and its application in Japanese soy sauce fermentation,J.Ind.Microbiol.Biotechnol.,32 383-390. http://dx.doi.org/10.1007/s10295-005-0257-7 